\title{
MECHANICAL AND ELECTRICAL PROPERTIES OF CAST AI-Er-Zr ALLOY
}

\author{
${ }^{1}$ Michal LEIBNER, ${ }^{1}$ Martin VLACH, ${ }^{1}$ Veronika KODETOVÁ, 'ozef VESELÝ, ${ }^{1}$ Hana KUDRNOVÁ, \\ ${ }^{1}$ Miroslav CIESLAR, ${ }^{1}$ Sebastien ZIKMUND, ${ }^{2}$ Vladivoj OČENÁŠEK, ${ }^{1,3}$ František LUKÁČ, \\ ${ }^{4}$ Vladimír MÁRA \\ ${ }^{1}$ Charles University, Faculty of Mathematics and Physics, Prague, Czech Republic, EU, \\ mleibner@seznam.cz \\ 2SVÚM a.s., Čelákovice, Czech Republic, EU \\ ${ }^{3}$ Academy of Sciences of the Czech Republic, Institute of Plasma Physics, Prague, Czech Republic, EU \\ ${ }^{4}$ Czech Technical University in Prague, Faculty of Mechanical Engineering, Prague, Czech Republic, EU
}

https://doi.org/10.37904/metal.2021.4222

\begin{abstract}
Mechanical and electrical properties of an Al-Er-Zr alloy were investigated. Microhardness and resistometry measurements were supplemented by transmission electron microscopy and scanning electron microscopy. Resistivity decreases during isochronal annealing take place within the following temperature intervals: 150$270{ }^{\circ} \mathrm{C}, 300-420{ }^{\circ} \mathrm{C}$ and $450-570{ }^{\circ} \mathrm{C}$. The isochronal microhardness curve reflects hardening effects at corresponding temperatures. However, no thermal effect was observed in the DSC curves ranging from $25^{\circ} \mathrm{C}$ to $600{ }^{\circ} \mathrm{C}$. A transmission electron microscopy observation of the alloy studied isochronally annealed up to $390^{\circ} \mathrm{C}$ revealed a high density of $L_{12}$-structured particles, some of which had nucleated on dislocations. The distinct electrical resistivity, as well as microhardness, changes are in all cases connected with the precipitation and evolution of the $\mathrm{Al}_{3} \mathrm{Er}, \mathrm{Al}_{3} \mathrm{Zr}$ and/or $\mathrm{Al}_{3}(\mathrm{Er}, \mathrm{Zr})$ particles.
\end{abstract}

Keywords: Precipitation hardening, Al-Er-Zr alloy, resistivity, TEM

\section{INTRODUCTION}

An addition of Sc to Al alloys increases drastically the strength of an Al alloy due to the formation of a high number density of $\mathrm{L}_{1}{ }_{2}$-structured $\mathrm{Al}_{3} \mathrm{Sc}$ precipitates coherent with the aluminum matrix $[1,2]$. Further addition of a trace amount of $\mathrm{Zr}$ leads to formation of ternary $\mathrm{L}_{2}-\mathrm{Al}_{3}(\mathrm{Sc}, \mathrm{Zr})$ precipitates. These ternary particles have both thermodynamic and kinetic tendencies to form a core-shell structure [3-6]. The resulting Zr-rich shell can retard the fast diffusing Sc and therefore impede the coarsening of the precipitates $[3,5,7]$.

However, the applications of Sc are restricted due to its high cost. Similarly to Sc, the heavy rare-earth element Er exhibits an $\mathrm{Al}-\mathrm{Al}{ }_{3} \mathrm{Er}$ eutectic reaction. $\mathrm{Al}_{3} \mathrm{Er}$ also exhibits a stable $\mathrm{L}_{2}{ }_{2}$ structure [8]. Er has a larger diffusivity than Sc [9, 10], and thus $\mathrm{Al}_{3} \mathrm{Er}$ precipitates nucleate and grow at low temperatures and therefore $\mathrm{Al}-\mathrm{Er}$ alloys suffer from an early loss of strength [11]. The high matrix/precipitate interfacial energy in case of $\mathrm{Al}_{3} \mathrm{Er}$ [12] also indicates low coarsening resistance. Fortunately, it was confirmed that the co-alloying of $\mathrm{Er}$ and $\mathrm{Zr}$ in $\mathrm{Al}$ leads to the precipitation of $\mathrm{L1}_{2}$-phase $\mathrm{Al}_{3}(\mathrm{Er}, \mathrm{Zr})$ particles. Li et al. [13] reported the core-shelled structure of $\mathrm{Al}_{3}(\mathrm{Er}, \mathrm{Zr})$ in a peak-aged $\mathrm{Al}-\mathrm{Er}-\mathrm{Zr}$ alloy. Just like in case of $\mathrm{Al}_{3}(\mathrm{Sc}, \mathrm{Zr})$, the shell rich in $\mathrm{Zr}$ can act as diffusional barrier enhancing the coarsening resistance of the precipitates [13].

Despite these findings, the Al-Er-Zr system has not been thoroughly studied and the description of nonhomogenised cast Al-Er-Zr alloys is missing. This article reports on the evolution of mechanical and electrical properties of a cast Al-Er-Zr alloy during isochronal annealing. 


\section{EXPERIMENTAL PROCEDURES}

A ternary as-cast alloy with nominal composition of $\mathrm{Al}-0.25 \mathrm{Er}-0.15 \mathrm{Zr}$ (wt\%) was studied. The samples were isochronally annealed from room temperature (RT) up to $570^{\circ} \mathrm{C}$ in steps of $30^{\circ} \mathrm{C} / 30 \mathrm{~min}$. Heat treatment was performed in a stirred silicone oil bath up to $240{ }^{\circ} \mathrm{C}$ (these steps were followed by quenching into liquid nitrogen) and in a furnace with an argon protective atmosphere above $240{ }^{\circ} \mathrm{C}$ (followed by quenching into water at RT).

The response of Vickers microhardness (HV0.3) to isochronal annealing was investigated by Wolpert Wilson Micro Vickers $401 \mathrm{MVD}$ at $\sim 10^{\circ} \mathrm{C}$.

Relative resistivity changes during the isochronal annealing were measured by DC four-point method with a dummy specimen in series at $77 \mathrm{~K}$ in liquid nitrogen bath.

Differential scanning calorimetry (DSC) was performed at heating rates of 5,10 and $20^{\circ} \mathrm{C} / \mathrm{min}$ in Netzsch DSC 204 Phoenix apparatus. A specimen of mass $\sim 10 \mathrm{mg}$ was placed in $\mathrm{Al}_{2} \mathrm{O}_{3}$ crucibles. Nitrogen flowed at the rate of $40 \mathrm{ml} / \mathrm{min}$ as a protective atmosphere.

The microstructural development was investigated by scanning electron microscopy (SEM) and transmission electron microscopy (TEM) using TESCAN MIRA I LMH, equipped with an X-ray BRUKER microanalyser for energy-dispersive spectroscopy (EDS) measurements, and JEOL 2200FS, respectively. TEM foils were cut from the aged specimens, ground to about $100 \mu \mathrm{m}$ and then electropolished with an electrolyte solution consisting of $30 \%$ nitric acid and $70 \%$ methanol at $-25^{\circ} \mathrm{C}$.

\section{RESULTS AND DISCUSSION}

Figure 1 displays the response of the microhardness HV0.3 and relative resistivity changes of the $\mathrm{Al}-0.25 \mathrm{Er}-$ $0.15 \mathrm{Zr}$ alloy to step-by-step isochronal annealing. The initial absolute value of resistivity was determined as $5.06 \pm 0.08 \mathrm{n} \Omega \cdot \mathrm{m}$. Three distinct decreases of resistivity can be seen in the annealing curve. These occur within the following temperature intervals: $150-270{ }^{\circ} \mathrm{C}, 300-420^{\circ} \mathrm{C}$ and $450-570{ }^{\circ} \mathrm{C}$, the last decrease being the sharpest. The microhardness increases slightly during the first drop of resistivity and peaks at $360^{\circ} \mathrm{C}$ (during the second one). The microhardness then drops at $420{ }^{\circ} \mathrm{C}$ before peaking again at $480{ }^{\circ} \mathrm{C}$ after which it reaches a plateau.

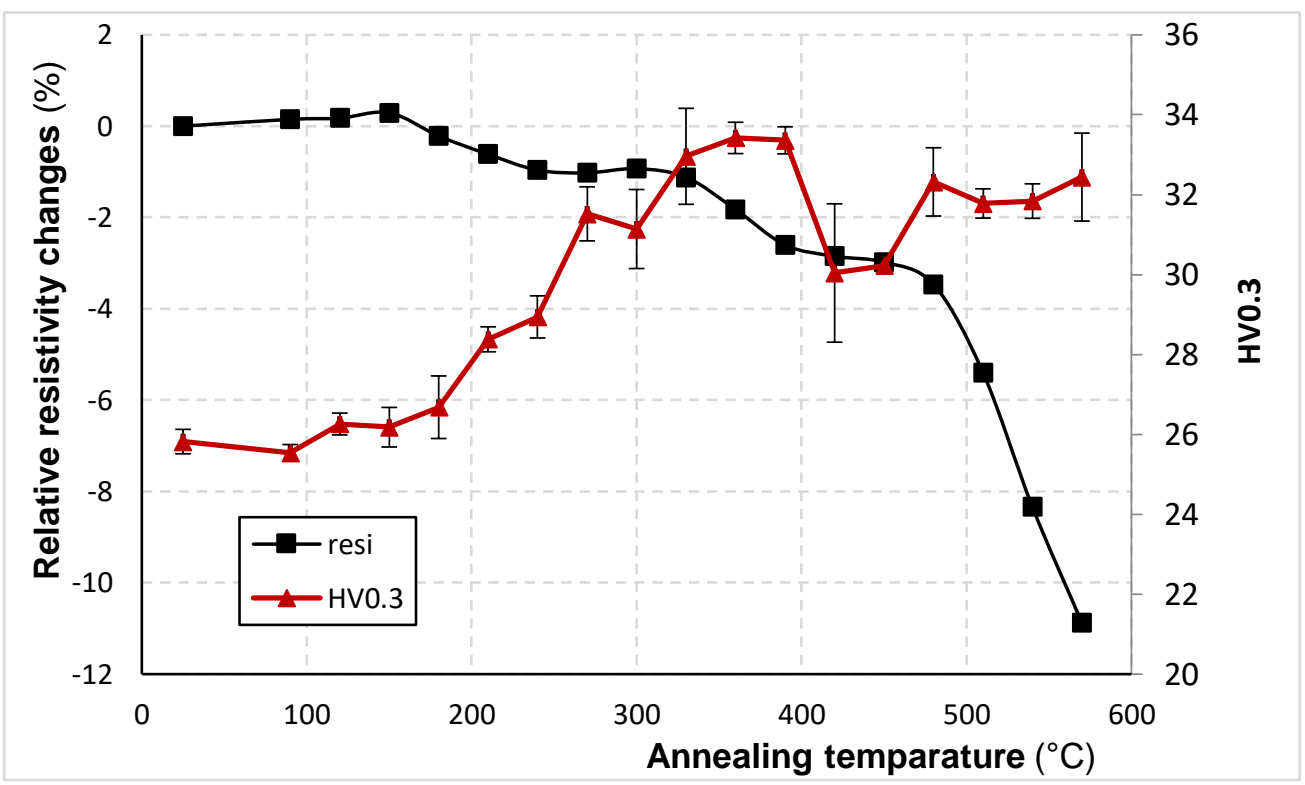

Figure 1 Isochronal annealing curves of resistivity and microhardness 
The DSC measurements in heating rates of 5,10 and $20^{\circ} \mathrm{C} / \mathrm{min}$ were done in the alloys in addition to resistivity and microhardness measurements. However, no thermal effect was observed in the DSC curves ranging from $25^{\circ} \mathrm{C}$ to $600^{\circ} \mathrm{C}$.

SEM micrograph of the alloy in the as-cast state (Figure 2) shows a high number density of Er-rich primary precipitates, as analyzed by EDS, indicating that the Er supersaturation in the Al matrix might be relatively low. The eutectic is enriched in Er only as Al-Zr alloys undergo a peritectic transformation [14]. Only small density of dislocations in grain interiors in the as-state of the alloy was observed by TEM. Considering that the number of grain boundaries (millimetre-size grains, roughly estimated from SEM observations) is also very low and do not change significantly during the aging process, the dominating contributing factor to the evolution of electrical resistivity is the change of solute concentrations in the matrix.

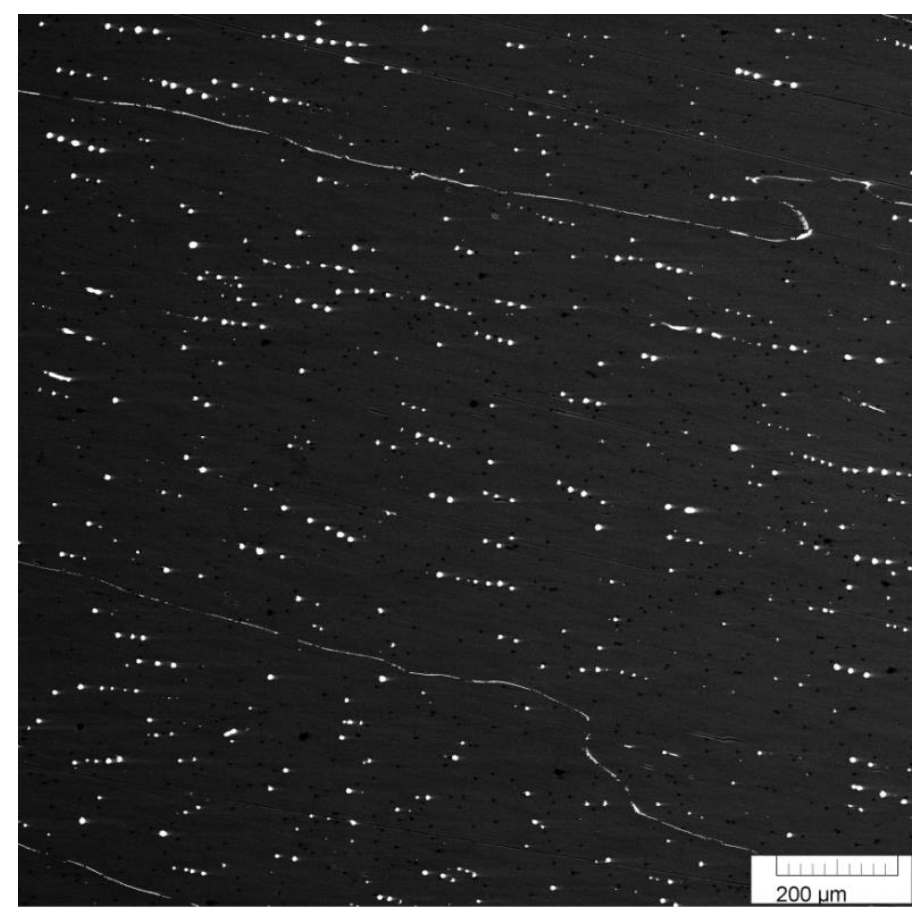

Figure 2 SEM micrograph of the as-cast microstructure

In the available literature focusing on $\mathrm{Al}-\mathrm{Er}-\mathrm{Zr}$ ternary and $\mathrm{Al}-\mathrm{Er}-\mathrm{Sc}-\mathrm{Zr}$ quaternary systems, $\mathrm{Er}$ is generally believed to precipitate first [12,13,15-18], owing to its high diffusivity [10], despite its high critical nucleation radius and critical work of nucleation [12]. The sluggishly diffusing $\mathrm{Zr}$ was reported to first precipitate above $400{ }^{\circ} \mathrm{C}$ even at lower effective heating rates of isochronal annealing $[15,16]$. Therefore, the second microhardness peak and the resistivity changes above $450^{\circ} \mathrm{C}$ can be ascribed to $\mathrm{Zr}$.

Figure 3 shows dark-field TEM micrograph of the alloy isochronally annealed up to $390^{\circ} \mathrm{C}$ taken with an $\mathrm{L} 1_{2}$ superlattice reflection. Based on the above, the displayed particles are most probably $\mathrm{Al}_{3} \mathrm{Er}$. The diffraction pattern shown in Figure 4 confirms the $L 1_{2}$ structure of the precipitates. The arrows in Figure 3 point at arrays of heterogeneously precipitated particles. Such arrayed precipitation was also observed in an Al-Sc alloy [19] and $\mathrm{Al}-\mathrm{Sc}-\mathrm{Ti}$ alloy [20] aged at small supersaturation. Low supersaturation means low thermodynamic driving force for nucleation and the precipitates nucleate predominately heterogeneously on dislocations to form an array [20]. The Er supersaturation in the present alloy has probably been considerably lowered by formation of the primary particles (see Figure 2). Moreover, the matrix/precipitate interfacial energy is higher for $\mathrm{Al}_{3} \mathrm{Er}$ (compared to $\mathrm{Al}_{3} \mathrm{Sc}$ ) [12] and so its precipitation can be expected to be even more affected by presence of preferential nucleation sites. 


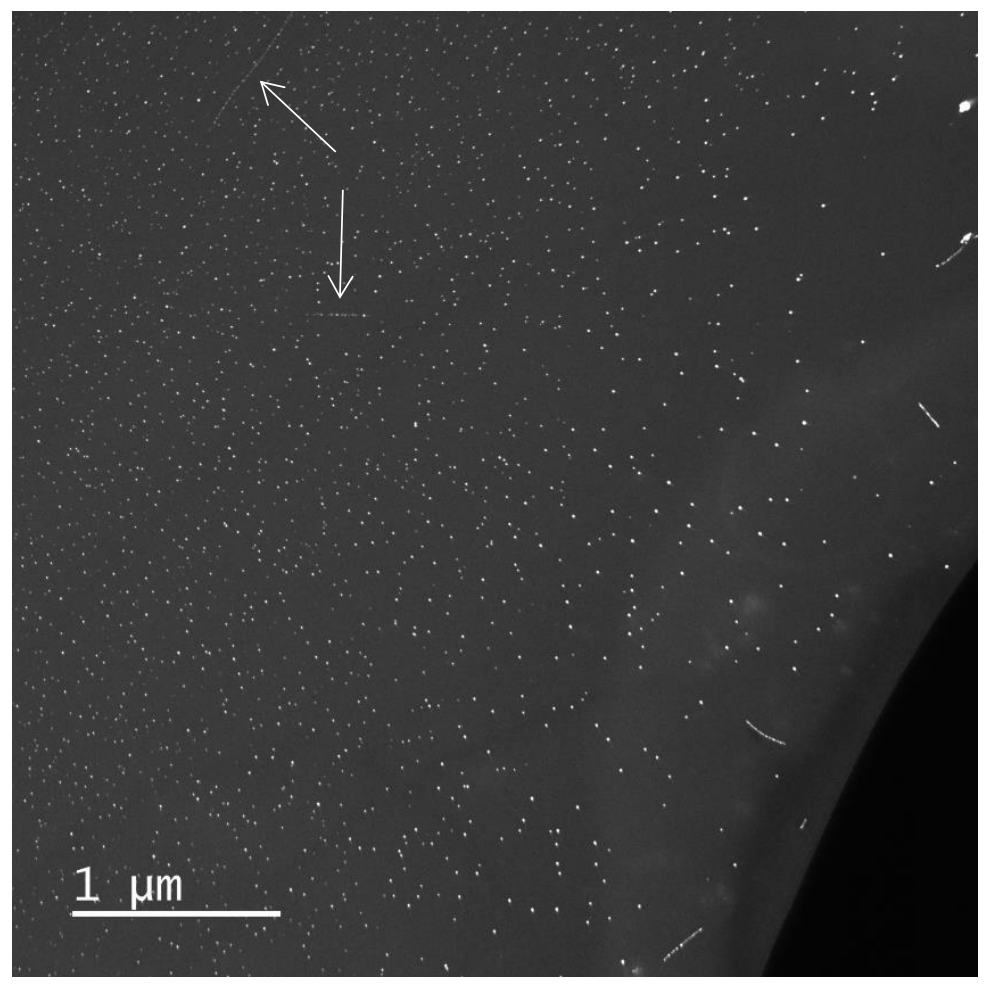

Figure 3 Dark-field TEM image of the alloy isochronally annealed up to $390^{\circ} \mathrm{C}$

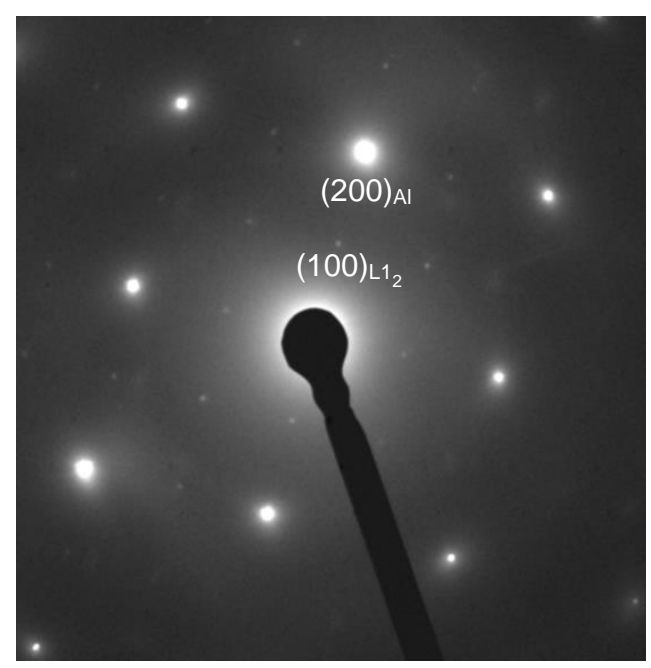

Figure 4 Selected area diffraction pattern of the alloy isochronally annealed up to $390{ }^{\circ} \mathrm{C}$ with weak $L 1_{2}$ reflections, beam parallel to [001]AI projection

So far, little effort has been made to describe the early stages of evolution of $\mathrm{Al}_{3} \mathrm{Er}$ particles. Vlach et al. [21] investigated phase transformations in an Al- $0.2 \mathrm{Sc}-0.15 \mathrm{Zr}$ alloy during isochronal annealing and found that prior to $\mathrm{Al}_{3} \mathrm{Sc}$ precipitation there was a slight decrease and increase in resistivity and microhardness, respectively. The suggested explanation - Sc clustering - was later proved by positron annihilation spectroscopy [22]. Analogically it can be proposed that the slight resistivity and microhardness changes between $150^{\circ} \mathrm{C}$ and $270^{\circ} \mathrm{C}$ (see Figure 1) are connected to clustering of Er. This statement, however, stems from the analogy to the similar Al-Sc system and is to be proved. Subsequently $\mathrm{Al}_{3} \mathrm{Er}$ are formed, resulting in drop of resistivity and peak hardness at about $360{ }^{\circ} \mathrm{C}$. The decline of microhardness at $420{ }^{\circ} \mathrm{C}$ is probably 
caused by coarsening of the $\mathrm{Al}_{3} \mathrm{Er}$ particles. Their dissolution would be accompanied by an increase of resistivity which was not observed.

Nieet al.[15] have reported that the number density of precipitates of Al-Er-Zr alloy is higher than that of Al$\mathrm{Er}$ alloy and there are core-shell $\mathrm{Al}_{3}(\mathrm{Er}, \mathrm{Zr})$ precipitates in the $\mathrm{Al}-\mathrm{Er}-\mathrm{Zr}$ alloy with core enriched in $\mathrm{Er}$ and shell enriched in Zr. First-principles calculations showed that this core-shell structure is the most stable among all possible precipitation structures in Al-Er-Zr and thus shall account for majority of precipitates [12]. At temperatures greater than $420^{\circ} \mathrm{C}$, the diffusivity of $\mathrm{Zr}$ becomes sufficiently large to permit significant diffusion and precipitation of this solute element on previously formed $\mathrm{Al}_{3} \mathrm{Er}$ precipitates, causing the second microhardness peak and subsequent microhardness plateau.

\section{CONCLUSIONS}

The properties of cast $\mathrm{Al}-\mathrm{Er}-\mathrm{Zr}$ alloy were investigated utilizing microhardness, electrical resistivity measurements, differential scanning calorimetry and observations by electron microscopy. Based on the obtained results, following conclusions can be made:

- The slight resistivity and microhardness changes between $150^{\circ} \mathrm{C}$ and $270{ }^{\circ} \mathrm{C}$ might stem from clustering of Er.

- The precipitation of $\mathrm{Al}_{3} \mathrm{Er}$ particles results in a pronounced hardening effect. Some of these particles nucleated on dislocations.

- $\quad$ No thermal effect was observed in the DSC curves ranging from $25^{\circ} \mathrm{C}$ to $600{ }^{\circ} \mathrm{C}$.

- Above $420^{\circ} \mathrm{C}, \mathrm{Zr}$ most likely precipitates on previously formed $\mathrm{Al}_{3} \mathrm{Er}$ nuclei, probably forming a $\mathrm{Zr}$-rich shell.

- In order to describe the decomposition sequence of the Al-Er-Zr system thoroughly, further investigations are required.

\section{ACKNOWLEDGEMENTS}

The study was supported by the Charles University, project GA UK No. 103-010/251591. ML acknowledges support by the project SVV-260582 (Specific Academic Research Projects, Charles University).

\section{REFERENCES}

[1] TOROPOVA, L.S., ESKIN, D.G., KHARAKTEROVA, M.L., DOBATKINA, T.V. Advanced aluminum alloys containing scandium - structure and properties. Amsterdam: Gordon and Breach Science Publisher, 1998. ISBN 90-5699-089-6.

[2] MICHNA, Š., LUKÁČ, I., OČENÁŠEK, V., KOŘENÝ, R., DRÁPALA, J., SCHNEIDER, H., MIŠKUFOVÁ, A. et al. Aluminium Materials and Technologies from A to Z. Slovakia, Adin s.r.o, Prešov, 2007. ISBN 80-89041-4 Encyklopedie hliníku. Prešov: Adin s.r.o., 2005. ISBN 978-80-89244-18-8.

[3] FULLER. C.B., SEIDMAN, D.N., DUNAND, D.C. Mechanical properties of Al(Sc,Zr) alloys at ambient and elevated temperatures. Acta Materialia. [online]. 2003, vol. 51, pp. 4803-4814. ISSN 1359-6454. Available from: https://doi.org/10.1016/S1359-6454(03)00320-3.

[4] KOLÁŘ, M., OČENÁŠEK, V., UHLíŘ, J., STULÍKOVÁ, I., SMOLA, B., VLACH, M., NEUBERT, V. SPERLINK, K. Effect of $\mathrm{Sc}$ and $\mathrm{Zr}$ additions on microstructure and mechanical properties of conventional cast and P/M aluminium. Materials Science Forum. [online]. 2008. vol. 567-568, pp. 357-360. Available from: https://doi.org/10.4028/www.scientific.net/MSF.567-568.357.

[5] KNIPLING, K.E., SEIDMAN, D.N., DUNAND, D.C. Ambient- and high-temperature mechanical properties of isochronally aged Al-0.06Sc, Al-0.06Zr and Al-0.06Sc-0.06Zr (at\%) alloys. Acta Materialia. [online]. 2011, vol. 59, pp. 943-954. ISSN 1359-6454. Available from: https://doi.org/10.1016/j.actamat.2010.10.017. 
[6] VLACH, M., KODETOVÁ, V., ČižEK, J., LEIBNER, M., KEKULE, T., LUKÁČ, F., CIESLAR, M., BAJTOŠOVÁ, L., KUDRNOVÁ, H., ŠíMA, V., ZIKMUND, S., ČERNOŠKOVÁ, E., KUTÁLEK, P., NEUBERT, V.D., NEUBERT, V. Role of small addition of Sc and $\mathrm{Zr}$ in clustering and precipitation phenomena induced in AA7075. Metals. [online]. 2021, vol. 11, no. 8. Available from: https://doi.org/10.3390/met11010008.

[7] KNIPLING, K.E., KARNESKY, R.A., LEE, C.P., DUNAND, D.C., SEIDMAN, D.N. Precipitation evolution in Al$0.1 \mathrm{Sc}, \mathrm{Al}-0.1 \mathrm{Zr}$ and Al-0.1Sc-0.1Zr (at\%) alloys during isochronal aging. Acta Materialia. [online]. 2010, vol. 58, pp. 5184-5195. ISSN 1359-6454. Available from: https://doi.org/10.1016/.actamat.2010.05.054.

[8] ZHANG, Y., GAO, K., WEN, S., HUANG, H., NIE, Z., ZHOU, D. The study on the coarsening process and precipitation strengthening of Al3Er precipitate in Al-Er binary alloy. Journal of Alloys and Compounds. [online]. 2014, vol. 610, pp. 27-34. ISSN 0925-8388. Available from: https://doi.org/10.1016/j.jallcom.2014.04.093.

[9] KNIPLING, K.E., DUNAND, D.C., SEIDMAN, D.N. Criteria for developing castable, creep-resistant aluminumbased alloys - A review. Zeitschrift für Metallkunde/Materials Research and Advanced Techniques. [online]. 2006, vol. 97, pp. 246-265. Available from: https://doi.org/10.3139/146.101249.

[10] VAN DALEN, M.E., KARNESKY, R.A., CABOTAJE, J.R., DUNAND, D.C., SEIDMAN, D.N. Erbium and ytterbium solubilities and diffusivities in aluminum as determined by nanoscale characterization of precipitates. Acta Materialia. [online]. 2009, vol. 57, pp. 4081-4089. Available from: https://doi.org/10.1016/j.actamat.2009.05.007.

[11] ZHANG, Y., GAO, K., WEN, S., HUANG, H., NIE, Z., ZHOU, D. The study on the coarsening process and precipitation strengthening of Al3Er precipitate in Al-Er binary alloy. Journal of Alloys and Compounds. [online]. 2014, vol. 610, pp. 27-34. Available from: https://doi.org/10.1016/i.jallcom.2014.04.093.

[12] ZHANG, C., YIN, D., JIANG, Y., WANG, Y. Precipitation of L12-phase nano-particles in dilute Al-Er-Zr alloys from the first-principles. Computational Materials Science. [online]. 2019, vol. 162, pp. 171-177. ISSN 0927-0256. Available from: https://doi.org/10.1016/i.commatsci.2019.03.001.

[13] HONGYING, L., JIE, B., JIAOJIAO, L., ZHAOHE, G., XIAOCHAO, L. Precipitation evolution and coarsening resistance at $400^{\circ} \mathrm{C}$ of Al microalloyed with Zr and Er. Scripta Materialia. [online]. 2012, vol. 67, pp. 73-76. ISSN 1359-6462. Available from: https://doi.org/10.1016/i.scriptamat.2012.03.026.

[14] FISCHER, E., COLINET, C. An updated thermodynamic modeling of the Al-Zr system. Journal of Phase Equilibria and Diffusion. [online]. 2015, vol. 36, pp. 404-413. Available from: https://doi.org/10.1007/s11669-015-0398-y.

[15] WEN, S.P., GAO, K.Y., LI, Y., HUANG, H., NIE, Z.R. Synergetic effect of $E r$ and Zr on the precipitation hardening of Al-Er-Zr alloy. Scripta Materialia. [online]. 2011, vol. 65, pp. 592-595. ISSN 1359-6462. Available from: https://doi.org/10.1016/.s.scriptamat.2011.06.033.

[16] BOOTH-MORRISON, C., DUNAND, D.C., SEIDMAN, D. N. Coarsening resistance at $400^{\circ} \mathrm{C}$ of precipitationstrengthened Al-Zr-Sc-Er alloys. Acta Materialia. [online]. 2011, vol. 59, pp. 7029-7042. ISSN 1359-6454. Available from: https://doi.org/10.1016/j.actamat.2011.07.057.

[17] DE LUCA, A., DUNAND, D.C., SEIDMAN, D.N. Mechanical properties and optimization of the aging of a dilute AlSc-Er-Zr-Si alloy with a high Zr/Sc ratio. Acta Materialia. [online]. 2016, vol. 119, pp. 35-42, ISSN 1359-6454. Available from: https://doi.org/10.1016/i.actamat.2016.08.018.

[18] VO, N.Q., DUNAND, D.C., SEIDMAN, D.N. Improving aging and creep resistance in a dilute Al-Sc alloy by microalloying with $\mathrm{Si}, \mathrm{Zr}$ and Er. Acta Materialia. [online]. 2014, vol. 63, pp. 73-85. ISSN 1359-6454. Available from: https://doi.org/10.1016/j.actamat.2013.10.008.

[19] MARQUIS, E.A., SEIDMAN, D.N. Nanoscale structural evolution of $\mathrm{Al}_{3} \mathrm{Sc}$ precipitates in $\mathrm{Al}(\mathrm{Sc})$ alloys. Acta Materialia. [online]. 2001, vol. 49, pp. 1909-1919, ISSN 1359-6454. Available from: https://doi.org/10.1016/S13596454(01)00116-1.

[20] VAN DALEN, M.E., DUNAND, D.C., SEIDMAN, D.N. Effects of Ti additions on the nanostructure and creep properties of precipitation-strengthened Al-Sc alloys. Acta Materialia. [online]. 2005, vol. 53, pp. 4225-4235. ISSN 1359-6454. Available from: https://doi.org/10.1016/j.actamat.2005.05.022.

[21] VLACH, M., STULÍKOVÁ, I., SMOLA, B., ŽALUDOVÁ, N., ČERNÁ, J. Phase transformations in isochronally annealed mould-cast and cold-rolled Al-Sc-Zr-based alloy. Journal of Alloys and Compounds. [online]. 2010, vol. 492, pp. 143-148. ISSN 0925-8388. Available from: https://doi.org/10.1016/j.jallcom.2009.11.126.

[22] VLACH, M., ČiŽEK, J., SMOLA, B., STULíKOVÁ, I., HRUŠKA, P., KODETOVÁ, V., DANIŠ, S., TANPRAYOON, D., NEUBERT, V. Influence of dislocations on precipitation processes in hot-extruded Al-Mn-Sc-Zr alloy. International Journal of Materials Research. [online]. 2018, vol. 109, pp. 583-592. Available from: https://doi.org/10.3139/146.111654. 